\title{
PERANAN IBU DALAM PEMEROLEHAN BAHASA ANAK USIA 4-5 TAHUN
}

\section{MOTHER'S ROLE IN LANGUAGE EMPLOYMENT CHILDREN AGE 4-5 YEARS}

\author{
Bella Choirunnisa \\ Universitas Islam Negeri Syarif Hidayatullah Jakarta \\ bella.choirunnisa17@mhs.uinjkt.ac.id
}

\begin{abstract}
Abstrak
Bahasa mempunyai peran penting di dalam kehidupan manusia sehari-hari, yaitu sebagai media komunikasi yang digunakan manusia untuk menyampaikan ide, perasaan, dan keinginan antara sesama manusia. Hal tersebut menarik perhatian para ahli untuk mengkaji bagaimana suatu bahasa diproses, kemudian digunakan manusia untuk berkomunikasi. Kajian itu disebut dengan ilmu "Psikolinguistik". Psikolinguistik merupakan kajian yang mempelajari mengenai proses di dalam diri seseorang yang berkaitan dengan cara mereka berbahasa. Proses tersebut antara lain komprehensi, produksi, landasan biologis serta pemerolehan bahasa. Usia 0-6 tahun adalah fase dimana seorang anak mengalami pertumbuhan dan perkembangan yang sangat pesat, oleh karena itu diperlukan penanganan yang tepat agar anak tersebut dapat tumbuh dan berkembang secara maksimal. Orang tua berperan besar dalam pemerolehan bahasa anak khususnya seorang ibu, karena seorang ibu lebih intensif dalam pertemuan dengan anaknya dibandingkan seorang ayah. Maka dari itu, penelitian ini akan memaparkan bagaimana peranan seorang ibu dalam pemerolehn bahasa anaknya yang berusia 4-5 tahun. Peneliti memilih responden bernama Adiba Kalisa Zahra yang berusia 4 tahun dan Rahma Salsabila berusia usia 5 tahun dalam percakapan dengan ibunya masing-masing. penelitian dilakukan di Desa Bojong Indah, Kecamatan Parung, Kabupaten Bogor.
\end{abstract}

Kata kunci: Psikolinguistik, Orang tua, Pemerolehan bahasa, anak usia 4-5 tahun

\begin{abstract}
Language has an important role in human life, namely as a communication tool used by bumans to convey ideas, feelings, and desires between fellow humans. It attracted the attention of linguists to study how language is processed, and used by humans so that it comes to communication events. The study was known as "Psycholinguistics". Psycholinguistics is a study that studies a person's mental processes in relation to language. The process includes comprehension, production, biological foundation and language acquisition. Early childhood is a child in the age range of 0-6 years who are experiencing rapid growth and development, so that proper stimulation is needed in order to grow and develop optimally. Parents play a major role in the acquisition of children's language, especially a mother, because a mother is more intensive in meeting with her child than a father. Therefore, this study will explain how the role of a mother in language acquisition of children aged 4-5 years. Researchers chose respondents named 4-year-old Adiba Kalisa Zabra and Rahma Salsabila aged 5 years in conversation with their respective mothers. the study was conducted in Bojong Indah Village, Parung District, Bogor Regency.
\end{abstract}

Key words: Psycholinguistics, Parents, Language acquisition, children aged 4-5 years 


\section{PENDAHULUAN}

Bahasa merupakan simbol bunyi yang bermakna dan berartikulasi (dihasilkan oleh alat ucap) bersifat arbitrer dan konvensional, yang digunakan sebagai media komunikasi oleh sekelompok manusia dengan tujuan melahirkan perasaan dan pemikiran. Bahasa Indonesia sebagai media komunikasi memiliki fungsi sebagai media untuk memberitahukan gagasan, perasaan, serta keinginan kepada orang lain agar dapat dimengerti dan diberi respon (Aini, 2013:3). Bahasa merupakan sesuatu yang penting di dalam kehidupan manusia. Dengan bahasa, manusia dapat mengekspesikan apa yang ada dipikiran dan yang ada di dalam perasaannya kepada orang lain. disisi lain, dengan bahasa manusia dapat mengerti maksud, tujuan, serta kehendak orang lain. Peran bahasa yang sangat penting di dalam kehidupan manusia itu, telah memunculkan rasa penasaran para ahli linguistik untuk mempelajari bagaimana suatu bahasa diproses serta dipakai oleh manusia. Sehingga sampai pada peristiwa komunikasi. Kajian ini disebut dengan ilmu "Psikolinguistik" (Nurbaya, 1997:53).

Lyons berpendapat bahwa psikolinguistik adalah suatu kajian mengenai produksi (sintesis) dan rekognisi (analisis). Pengertian yang hampir sama dikemukakan Bach. Psikolinguistik merupakan ilmu yang meneliti bagaimana sebenarnya para pembicara atau pengguna bahasa membentuk atau membangun serta memahami kalimat-kalimat bahasa tersebut. Sedangkan menurut Slobi. Psikolinguistik adalah ilmu yang menjelaskan tahapantahapan psikologi yang berlangsung ketika seseorang mengujarkan kalimat-kalimat yang didengarnya pada saat mereka berkomunikasi dan bagaimana kemampuan berbahasa itu didapat (Suhardi, 2013:21). Sementara itu, Harley (dalam Dardjowidjojo, 2010:43) mengatakan psikolinguistik merupakan kajian tentang tahapan-tahaoan mental dalam penggunaan bahasa.

Berdasarkan beberapa pendapat di atas, pada prinsipnya psikolinguistik adalah kajian hibrida, yang muncul dari dua istilah yaitu psikologi dan linguistik. Psikologi dikenal sebagai ilmu jiwa. Sementara linguistik dikenal sebagai ilmu bahasa. Akan tetapi, psikolinguistik tidak sesederhana itu. Menurut Dardjowidjojo (2010:31), psikolinguistik merupakan kajian yang mempelajari tahapan-tahapan dalam diri manusia yang dialami oleh manusia ketika mereka berbahasa.

Lebih jauh, Dardjowidjojo (2010:32) menyimpulkan empat topik yang dipelajari di dalam psikolinguistik. Empat topik tersebut adalah:

1. Komprehensi. Komprehensi terkait dengan tahapan dalam diri manusia yang harus dilewati menusia sehingga mereka mampu memahami segala sesuatu yang dikatakan oleh orang lain dan mengerti makna dan tujuan dari komunikasi tersebut.

2. Produksi. Produksi berkaitan dengan tahapan dalam diri manusia yang menjadikan manusia bisa mengkomunikasikan sesuatu seperti dikatakan.

3. Landasan biologis dan neurologis. Landasan biologis dan neurologis adalah sesuatu yang menjadikan manusia bisa berbahasa.

4. Pemerolehan bahasa. Pemerolehan bahasa yaitu suatu cara memperhatikan kegiatan anak-anak dalam mendapati bahasa mereka (Nuryani dan Putra, 2013:58).

Dari pemaparan tersebut, bisa disimpulkan bahwa psikolinguistik adalah campuran dari dua istilah yakni psikologi dan linguistik yang membahas mengenai tahapan dalam diri seseorang dengan kaitannya dengan berbahasa. Proses tersebut antara lain komprehensi, 
produksi, landasan biologis serta pemerolehan bahasa. Penelitian kali ini akan membahas bagaimana proses berbahasa anak usia 4-5 tahun dalam pemerolehan bahasanya terkait dengan peran orang tua khususnya ibu.

Dardjowidjojo (2010:33) berpendapat bahwa pemerolehan digunakan untuk tahapan penguasaan bahasa yang dikerjakan seorang anak secara alami pada saat ia mempelajari bahasa ibunya. Sedangkan Chaer menyatakan bahwa pemerolehan bahasa merupakan tahapan yang terjadi di dalam otak seorang anak saat ia memperoleh bahasa pertamanya atau bahasa ibunya. sementara itu, pendapat lain yang dikatakan oleh Krashen menjelaskan bahwa pemerolehan bahasa merupakan tahapan bagaimana seseorang mampu berbahasa atau tahapan anak-anak pada umumnya memperoleh bahasa pertama atau bahasa ibunya (Fatmawati, 2015:66). Dari penjelasan di atas, dapat disimpulkan bahwa pemeroehan bahasa adalah suatu tahapan yang terjadi di dalam otak anak secara natural saat ia memperoleh bahasa pertamanya atau bahasa ibunya.

Terdapat tiga teori mengenai pemerolehan bahasa pada anak yang saling bertolak belakang, yaitu teori behavioristik, teori mentalistik, dan teori pemerolehan bahasa kognitif. Menurut penglihatan behavioristik, anak sejak lahir tidak membawa struktur linguistik. Artinya, anak yang lahir dianggap kosong dari bahasa. Brown menganggap bahwa anak lahir ke dunia diartikan sebagai kain putih tanpa catatan atau coretan dan lingkungan akan membentuknya secara perlahan terhadap tingkah lakunya. Kaum mentalis atau rasionalis berpendapat, tahapan pemerolehan bahasa bukan sebagai hasil dari proses belajar, melainkan karena sejak lahir anak telah mempunyai sejumlah kapasitas atau potensi bahasa yang akan berkembang sesuai dengan tahapan kematangan intelektualnya. Sedangkan menurut penganut teori kognitif, stimulus adalah input bagi si anak yang kemudian berproses dalam otak. Pada otak terjadi mekanisme internal yang diatur oleh pengatur kognitif yang kemudian keluar sebagai hasil pengolahan kognitif (Nuryani dan Putra, 2013:101).

Anak merupakan anugerah bagi orang tua. Di tangan orang tualah anak akan tumbuh dan berkembang. Usia 0-6 tahun adalah fase dimana seorang anak mengalami pertumbuhan dan perkembangan yang sangat pesat, oleh karena itu diperlukan penanganan yang tepat agar anak tersebut dapat tumbuh dan berkembang secara maksimal (Mulyati, 2019:12). Kualitas bahasa yang dipakai orang-orang disekitarnya akan mempengaruhi keterampilan anak dalam berbicara atau berbahasa (Syafitri, 2017:3). Keluarga sangat erat kaitannya dengan baik atau tidaknya pemerolehan bahasa pada anak. Peran keluarga adalah memenuhi kebutuhan anak serta memberikan pendidikan kepada anak. Selain itu gaya pengasuhan yang orang tua pakai, berperan dalam pemerolehan bahasa anak. Yusuf (2009:17) berpendapat bahwa salah satu faktor yang mempengaruhi perkembangan bahasa ialah cara komunikasi dalam keluarga. Dengan pola pengasuhan yang tepat, pemerolehan bahasa dan jenis perkembangan lainnya dapat berkembang dengan baik, begitu juga sebaliknya (Syafitri, 2017:4).

Orang tua berperan besar dalam perkembangan bahasa anak khususnya seorang ibu, karena seorang ibu lebih intensif dalam pertemuan dengan anaknya dibandingkan seorang ayah. Maka dari itu, penelitian ini akan memaparkan bagaimana peranan seorang ibu dalam pemerolehn bahasa anaknya yang berusia 4-5 tahun. Peneliti memilih responden bernama Adiba Kalisa Zahra yang berusia 4 tahun dan Rahma Salsabila berusia usia 5 tahun yang 
tinggal di Desa Bojong Indah, Kecamatan Parung, Kabupaten Bogor. Penelitian ini akan menggunakan teori behavioristik dalam mengkaji pemerolehan bahasa pada anak, berupa faktor orang tua khususnya ibu dalam pemerolehan bahasa tersebut, dengan cara memperhatikan komunikasi antara ibu dan anak.

\section{METODE}

Penelitian ini menggunakan penelitian deskriptif dimana peneliti berusaha mendeskripsikan serta menganalisis fenomena atau peristiwa tertentu dengan menggunakan peneliti sebagai instrumen utama, teknik pengumpulan datanya secara trianggulasi serta hasilnya lebih menekankan pada aspek makna. Hal ini senada dengan dengan pernyataan Moleong (2017:11) bahwa pendekatan deskriptif data adalah berupa kata-kata, gambar, serta bukan angka-angka. Penelitian ini mengambil narasumber dua orang anak kecil bernama Rahma Salsabila yang berumur 5 tahun dan Adiba Kalisa Zahra berumur 4 tahun di Desa Bojong Indah Kecamatan Parung, Kabupaten Bogor, dengan menggunakan teknik penelitian berupa percakapan yang terjadi antara keduanya dengan ibunya masing-masing dan kemudian ditranskip ke dalam tulisan.

\section{HASIL DAN PEMBAHASAN}

Proses pemerolehan bahasa pada anak terjadi secara bertahap yaitu tahap peniruan, tahap memahami makna, dan tahap memakai kata dalam komunikasi (Nuryani, 2013:27). Pada tahap peniruan, si anak akan secara alami menirukan apa saja yang sengaja diperdengarkan atau tidak kepadanya. Tahap memahami makna ialah saat anak mulai memahami makna kata, sedangkan tahap memakai kata dalam komunikasi adalah tahapan saat anak sudah mampu memakai kata-kata yang diperolehnya.

Tahap pertama (tahap peniruan), orang tua perlu menyadari bahwa segala sesuatu yang tidak sengaja didengar atau yang sengaja diperdengarkan kepada anak akan secara alami ditiru, baik kata-kata yang bermakna baik, maupun yang bermakna buruk. Orang tua harus memberikan contoh yang baik dalam berkomunikasi, berusaha menciptakan suasana penggunaan bahasa yang baik ketika berkomunikasi dengan anak. Dalam teori penggunaan bahasa, ada kemungkinan bahwa anak-anak akan secara alami mengingat kata-kata yang bermakna baik dan indah demikian juga dengan kata-kata yang bermakna buruk dan jelek, baik dari segi bunyi maupun dari segi maknanya.

Pada tahap kedua (tahap memahami makna), orang tua dapat menerapkan pembelajaran yang akan memperbanyak kosa-kata si anak. Bisa berupa pengenalan nama benda di sekitarnya, perbedaan satu kata dengan kata lainnya, dan memaparkan kata berdasarkan kesamaannya.

Tahap ketiga (tahap pemakaian kata dalam komunikasi), orang tua dapat berperan dalam komunikasi yang dilakukan sang anak. Jika si anak menggunakan kata-kata yang kurang tepat, baik dari segi bunyi maupun makna, orang tua dapat melakukan koreksi terhadap kesalahan yang dibuat si anak. Dengan cara memberitahukan posisi kesalahan bahasanya sekaligus memberikan jawaban yang benar, sehingga si anak dapat memahami kata yang baik 
dan kata yang buruk, serta dapat mengetahui kata yang tepat dan kata yang tidak tepat (Nurbaya dan Mujinem, 1997:55).

Contoh 1

Percakapan seorang ibu dengan anaknya yang bernama Adiba berusia 4 tabun:

Ibu : "Push-push", (sambil menjentikekan tangan)

Anak : "Push-push, sini"

Ibu : "Bawa ke sini kucingnya de" (panggilan ke anaknya)

Anak : Mendekati kucing tersebut tetapi kembali lagi) "Takut mah kucingnya galak"

Ibu : "Baik ko"

Tabel 1. Contoh Pemerolehan Bahasa

\begin{tabular}{cccc}
\hline Ujaran ibu & $\begin{array}{c}\text { Ujaran atau tindakan } \\
\text { anak }\end{array}$ & $\begin{array}{c}\text { Tahap pemerolehan } \\
\text { bahasa }\end{array}$ & Makna kata \\
\hline "Push-push" & Push-push, sini & Peniruan & Memanggil kucing \\
\hline "Bawa ke sini & $\begin{array}{c}\text { Mendekati kucing } \\
\text { kucingnya de" } \\
\text { tersebut tetapi kembali } \\
\text { lagi) }\end{array}$ & Memahami makna & $\begin{array}{c}\text { Membawa kucing } \\
\text { mendekat dengan } \\
\text { sang ibu }\end{array}$ \\
\hline "Baik ko" & "Takut mah kucingnya & $\begin{array}{c}\text { Menggunakan kata } \\
\text { dalam komunikasi }\end{array}$ & $\begin{array}{c}\text { Takut dengan } \\
\text { kucing karena } \\
\text { kucingnya galak }\end{array}$ \\
\hline
\end{tabular}

Dari percakapan di atas dapat diketahui bahwa kalimat "push-push" yang diucapkan ibunya diikuti atau ditiru sang anak untuk memanggil kucing. Pada saat ibunya menyuruh mengambil kucing tersebut, si anak mengerti maksudnya dan pergi mendekati kucing tersebut. hal itu menandakan bahwa panggilan "push-push" yang ia tirukan dari sang ibu memiliki arti kucing dan ibunya menyuruh untuk membawa kucing tersebut mendekat dengan sang ibu. Namun pada akhirnya si anak kembali lagi ke ibunya dan mengucapkan bahwa ia takut karena kucingnya galak. Itu menandakan bahwa si anak sudah dapat mengucapkan kalimat untuk berkomunikasi dengan ibunya. Tetapi di akhir sang ibu meyakini bahwa kucing tersebut baik.

Contoh 2:

Percakapan seorang ibu dengan anaknya yang bernama Rabma berusia 5 tabun:

Ibu : "Abisin makanan itu dulu ntar ibu beliin maenan"

Anak : "Iya Rabma abisin"

Ibu : "Tanji?"

Anak : "Tanji." 
Tabel 2. Contoh Pemerolehan Bahasa

\begin{tabular}{|c|c|c|c|}
\hline Ujaran Ibu & $\begin{array}{l}\text { Ujaran } \\
\text { Anak }\end{array}$ & $\begin{array}{c}\text { Tahap Pemerolehan } \\
\text { Bahasa }\end{array}$ & Makna Kata \\
\hline \multirow[t]{2}{*}{$\begin{array}{l}\text { "Abisin makanan } \\
\text { itu dulu ntar ibu } \\
\text { beliin maenan" }\end{array}$} & "abisin" & Peniruan & $\begin{array}{l}\text { Ibu akan membelikan } \\
\text { mainan kepada anaknya jika } \\
\text { ia menghabiskan makanan } \\
\text { tersebut }\end{array}$ \\
\hline & $\begin{array}{l}\text { "Iya } \\
\text { Rahma } \\
\text { abisin" }\end{array}$ & Pemahaman makna & $\begin{array}{l}\text { Si anak ingin dibelikan } \\
\text { mainan baru oleh ibunya } \\
\text { tetapi harus menghabiskan } \\
\text { makanan terlebih dahulu }\end{array}$ \\
\hline "Janji?" & "Janji." & $\begin{array}{c}\text { Menggunakan kata dalam } \\
\text { komunikasi }\end{array}$ & $\begin{array}{l}\text { Tidak akan berbohong dan } \\
\text { akan segera menghabiskan } \\
\text { makanan tersebut }\end{array}$ \\
\hline
\end{tabular}

Percakapan di atas menceritakan bahwa si ibu akan membelikan mainan kepada anaknya jika ia menghabiskan makanan tersebut. Namun pada percakapan kali ini si ibu menggunakan kata yang tidak baku yang mengakibatkan si anak juga mengikuti bahasa yang tidak baku, yang seharusnya "Habiskan makanan itu, nanti ibu belikan mainan". Anak yang belum mengerti bahasa yang baik atau buruk hanya mengikuti apa yang ia dengar dari ibunya. Tetapi terdapat pula pemahaman makna pada kalimat "iya Rahma abisin". Kalimat tersebut mempunyai makna bahwa anak tersebut ingin dibelikan mainan baru oleh ibunya tetapi harus menghabiskan makanan tersebut terlebih dahulu. Kemudian dengan pemahaman makna kalimat tersebut si anak membuat ujaran dengan mengucap kata "janji” dengan maksud tidak akan berbohong dan akan segera menghabiskan makanan tersebut. Dengan demikian si anak telah mampu mengkomunikasikan sesuatu hal yang ingin ia sampaikan pada ibunya.

Dari kedua percakapan tersebut dapat diperoleh kesimpulan bahwa anak pada pemerolehan bahasanya memiliki tiga tahap, yakni tahap peniruan, tahap pemahaman makna, dan menggunakan kata dalam berkomunikasi. Pada contoh 1 diperoleh tahap peniruan pada kata "push" yang diucapkan ibunya dalam memanggil seekor kucing. Sedangkan pada contoh 2 diperoleh tahap peniruan pada kata "abisin”. Keduanya sama-sama diperdengarkan bahasa yang tidak baku. Hal tersebut membuat anak juga mengujarkan bahasa tidak baku dalam komunikasinya. Karena pada usia 4-5 tahun tersebut, anak belum mengerti mana yang bahasa baku dan tidak. Anak hanya menirukan apa yang didengarnya dari lingkungan sekitar.

Kemudian pada contoh 1 diperoleh tahap pemahaman makna lebih kepada tindakannya, yaitu tindakan mendekati kucing yang dimaksud oleh si ibu. Dengan tindakan tersebut, si anak telah memahami makna yang dituturkan oleh ibunya yaitu menyuruhnya mendekati kucing tersebut dan membawanya mendekat dengan sang ibu. Sedangkan pada contoh 2 diperoleh tahap pemahaman makna yang terdapat pada kalimat "iya Rahma abisin". Dengan kalimat tersebut, si anak telah memahami maksud si ibu yang menyuruhnya untuk menghabiskan makanan yang ada di dekatnya. Pada tahap ini terdapat perbedaan antara kedua contoh tersebut dalam memahami makna yang di maksud oleh ibunya masing-masing. 
pada contoh 1 pemahaman makna dilakukan dengan tindakan, sedangkan pada contoh 2 pemahaman makna dilakukan dengan ucapan.

Pada contoh 1 diperoleh tahap menggunakan kata dalam berkomunikasi pada kalimat "takut mah kucingnya galak". Dengan kalimat tersebut, si anak bermaksud mengatakan bahwa ia takut kepada kucing karena kucing tersebut galak, yang mengakibatkan ia kembali lagi ke ibunya tanpa membawa kucing tersebut. Sedangkan pada contoh 2 diperoleh tahap menggunkan kata dalam berkomunikasi pada kata "berjanji”. Dengan kalimat tersebut si anak telah mampu membedakan kata "berjanji" yang diucapkan ibunya dengan kata "berjanji" yang ia ucapkan. Dengan kata "berjanji" yang si anak ucapkan, ia bermaksud meyakinkan si ibu bahwa apa yang ia kerjakan tidak akan membohongi si ibu. Berbeda dengan kata "berjanji”" yang si ibu ucapkan untuk menanyakan atau menagih pembuktian dari si anak atas tindakannya.

\section{KESIMPULAN}

Bahasa mempunyai peran penting dalam kehidupan sehari-hari, yaitu sebagai media komunikasi yang digunakan manusia untuk memberitahukan ide, perasaan, dan keinginan antara sesama manusia. Orang tua berperan besar dalam pemerolehan bahasa anak khususnya seorang ibu, karena seorang ibu lebih intensif dalam pertemuan dengan anaknya dibandingkan seorang ayah. Berdasarkan pemaparan diatas, terdapat dua percakapan antara ibu dan anak yang menjelaskan adanya tahapan-tahapan anak dalam memperoleh bahasanya melalui lingkungan sekitarnya. Tahapan tersebut adalah tahap peniruan, tahap memahami makna, dan tahap pemakaian kata dalam komunikasi. Orang tua berperan besar dalam pemerolehan bahasa anak khususnya seorang ibu, karena seorang ibu lebih intensif dalam pertemuan dengan anaknya dibandingkan seorang ayah. Oleh karena itu, seorang ibu seharusnya dapat lebih bijak dalam mengucapkan suatu hal. Karena anak akan senantiasa menirukan sesuatu yang dikatakan oleh orang disekelilingnya yang bertujuan agar anak dapat memperoleh dan memakai bahasa yang tepat.

\section{DAFTAR PUSTAKA}

Aini, Nur. "Bahasa Indonesia Sebagai Alat Media Komunikasi Sehari-Hari”. Universitas Mitra Indonesia. Sistem Informasi.

Dardjowidjojo, Soejono. (2010). Psikolinguistik Pengantar Pemahaman Bahasa Manusia. Jakarta: Yayasan Obot Indonesia.

Fatmawati, Suci Rani. "Pemerolehan Bahasa Pertama Anak Menurut Tinjauan Psikolinguistik”. Lentera, Vol. Xviii, No. 1, Juni 2015.

Mulyati, Yeti., dkk. (2019). Bahasa Indonesia, Tangerang Selatan: Penerbit Universitas Terbuka, Cetakan ke-20.

Nurbaya, Siti. dan Mujinem, "Pemerolehan Bahasa Anak dan Peranan Orang Tua".Cakrawala Pendidikan No. 3, Tahun XVI, November 1997.

Nuryani dan Dona Aji Karunia Putra, Psikolinguistik, (Tanggerang Selatan: Mazhab Ciputat, 2013). 


\section{Bella Choirunnisa}

\section{Universitas Islam Negeri Syarif Hidayatullah Jakarta}

Nuryani dan Dona Aji Karunia Putra. (2013). Psikolinguistik. Tangerang Selatan: Mazhab Ciputat.

Prasetiyo, Deni Dwi. "Tindak Tutur Langsung dan Tak Langsung dalam Naskah Drama Asmarangkara Karya Trias Kurniawan”. Skripsi Universitas Nusantara PGRI Kediri 2018.

Suhardi. (2013). Pengantar Linguistik Umum. Jogjakarta: Ar-ruzz Media.

Syafitri. "Identifikasi Peran Keluarga dalam Mengembangkan Bahasa Anak Usia Dini di Kelurahan Olak Kemang Kota Jambi”. Fkip Universitas Jambi, 2017.

Yusuf, S. (2009). Psikologi Perkembangan Anak \& Remaja. Bandung: Remaja Rosdakarya. 